\title{
MODIFIKASI ALGORITMA ELEMINASI DERAU IMPULSIF DALAM KOMUNIKASI DATA DI 8-OFDM
}

\author{
Feri Fahrianto, M.Sc \\ Staff Pengajar Program Studi Teknik \\ Informatika \\ Fakultas Sains dan Teknologi \\ Universitas Islam Negeri Syarif \\ Hidayatullah Jakarta \\ Tel : (021) 32977989 \\ e-mail:feri.fahrianto@uinjkt.ac.id
}

\begin{abstract}
Impulsive noise error cancellation in Orthogonal frequency division multiplexing (OFDM) system plays crucial role to determine overall performance bit error rate (BER). An algorithm of impulsive noise error cancellation, particularly for small size OFDM, was introduced by Jack K. Wolf in 1983. This algorithm determines parallelism between OFDM and Reed Solomon Code. Employing two zeros as redundancy in consecutive way in the transmitted data, the algorithm is capable to correct one additive impulsive noise error in the channel. Nevertheless, the estimation of amplitude impulsive noise is still poor. This caused by Gaussian amplification factor in the estimation amplitude of impulsive noise technique introduced by Jack $K$. Wolf. By removing this amplification factor the paper showing a better result in BER.
\end{abstract}

\section{PENDAHULUAN}

Orthogonal Frequency Division

Multiplexing atau disingkat dengan OFDM dapat meningkatkan efisiensi bandwith apabila dibandingkan dengan teknik komunikasi data biasa seperti FDM, FM, AM. OFDM dapat mengirimkan multipel data melalui beberapa subkanal yang saling orthogonal satu dengan lainnya melalui bandwith frekuensi yang sama dengan komunikasi data biasa. Data tersebut dikirimkan tanpa terjadi interferensi oleh karena intergonalitas yang ada pada masing - masing subkanalnya. Tetapi hal utama yang menyebabkan terjadinya kesalahan dalam komunikasi data di OFDM adalah derau yang bersifat impulsif. Derau impulsive dalam OFDM skala kecil misalkan 8-OFDM akan didistribusikan ke masing-masing subkanal penerima yang disebabkan oleh struktur Fast Fourier Transform (FFT) yang ada dalam di sisi penerima.

OFDM dengan subkanal yang besar atau berskala besar dapat menggunakan pendekatan distribusi Gauss untuk mereduksi kesalahan yang terjadi dalam komunikasi datanya. Namun hal ini tidak bisa dilakukan untuk OFDM yang berskala kecil seperti 8-OFDM. Ada algoritma yang dipekernalkan untuk mengkoreksi kesalah yang disebabkan oleh derau impulsive pada OFDM berskala kecil yaitu Zero Consecutive Algorithm yang diperkenalkan oleh Jack K. Wolf pada tahun 1983. Dengan menggunakan sindrom yang berbentuk data redundansi yang bernilai nol dapat mendeteksi posisi dimana dan berapa besaran derau impulsive yang terjadi dalam komunikasi data.

\section{TEORI DASAR}

2.1. OFDM

$\begin{array}{ccr}\text { Orthogonal } & \text { Frequency } & \text { Division } \\ \text { Multiplexing (OFDM) } & \text { sama saja dengan }\end{array}$ menngirimkan data dengan modulasi frekuensi melalui multipel subkanal. Keuntungan dari OFDM adalah kemampuannya untuk memaksimalkan efisiensi dari bandwith yang tersedia dengan menggunakan N-Subfrekuensi pembawa untuk mendapatkan paralelisme dalam transmisi data. OFDM pada kenyataannya berasal dari Frequency Division Multiplexing (FDM). Perbedaan yang utama hanya terletak pada ortogonalitas di subfrekuensi pembawanya saja. Inverse Discrete Fourier Transform (IDFT) digunakan dalam OFDM untuk mengubah sinyal dari domain frekuensi ke domain waktu begitu juga sebaliknya Discrete Fourier Transform (DFT) akan digunakan disisi penerima untuk merubah kembali bentuk sinyal kedalam domain frekuensi. 


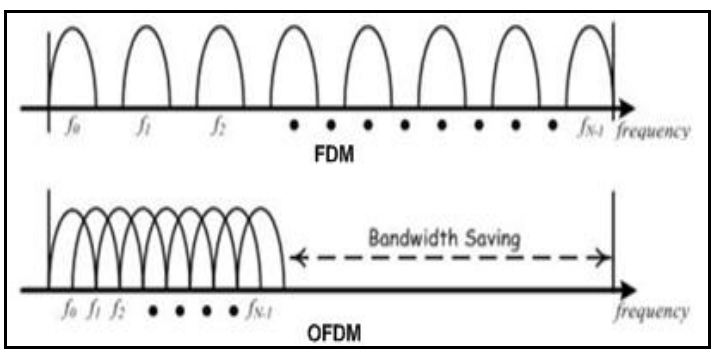

Gambar 1. FDM dan OFDM

OFDM dapat mengatasi interferensi data dengan efektif di sisi penerima kerena keunggulan yang disebabkan oleh ortogonalitas antara subkanal pembawa.

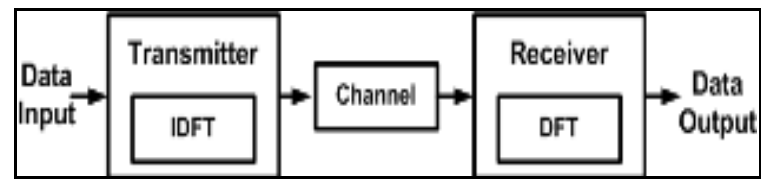

Gambar 2. Dasar Transmisi Data dalam OFDM

Sebuah modulasi OFDM dapat diimplementasikan sebagai N-IDFT pada suatu blok N-simbol informasi. Secara nyata IDFT di implementasikan dengan komputasi Inverse Fast Fourier transform (IFFT). Misalkan $\left\{S_{k}, k=\right.$ $1, \ldots, N\}$ merepresentasikan blok $\mathrm{N}$-simbol data yang kompleks yang di ambil dari sinyal konstelasi yang sesusai seperti Quadrature Amplitude Modulation $(Q A M)$. Maka IDFT dari satu buah blok data adalah

$\mathrm{S}_{(n)}=\frac{1}{\sqrt{N}} \sum_{k=0}^{N-1} s_{(k)} e^{e^{\left(\frac{12 \pi n k}{N}\right)}}$, dimana, $n=1, \ldots, N-1$

Dan DFT dari blok datanya adalah

$\mathrm{S}_{(\mathrm{k})}=\frac{1}{\sqrt{N}} \sum_{\mathrm{k}=0}^{N-1} S_{(\mathrm{n})} e^{\left[-\frac{\sqrt{2 \pi n n} \mathrm{k}}{N}\right]}$, dimana, $k=1, \ldots, N-1$.

Sinyal dikatakan ortogonal jika perkalian dalam satu perioda simbol dengan symbol lainnya adalah nol, dan antara sinyal itu sendiri adalah sama dengan $C$, yang merupakan konstanta energi dari sinyal symbol itu sendiri. Hal ini dirumuskan secara matematis sebagai

$\int_{0}^{T} S_{i}(t) S_{j}^{*}(t) d t=\left\{\begin{array}{l}0 \text { for } i \neq j \\ C \text { for } i=j\end{array}\right.$

Apabila $\left\{\stackrel{\rightleftarrows}{S}=S_{0}, S_{1}, S_{2}, \ldots, S_{N-1}\right\}$ menunjukkan simbol data. Teknik pemrosesan sinyal digital, bukan synthesizer frekuensi, dapat digunakan untuk menghasilkan ortogonal sub-carrier. DFT sebagai transformasi linear memetakan data simbol kompleks $\left\{\vec{s}=S_{0}, S_{1}, S_{2}, \ldots, S_{N-1}\right\}$ ke $\{\vec{s}=$ $\left.s_{0}, s_{1}, s_{2}, \ldots, s_{N-1}\right\}$ OFDM simbol sehingga Pemetaan linear dapat direpresentasikan simbol dalam bentuk vektor matriks sebagai,

$$
\vec{s}=\frac{1}{\sqrt{N}} \vec{W} \cdot \vec{s},
$$

dan transfrom kembali dalam bentuk matriks,

$\vec{s}=\frac{1}{\sqrt{N}} \vec{W}^{-1} \cdot \vec{s}$

Dimana menunjukan bentuk DFT vaktor matriks,

$$
\vec{W}=\left[\begin{array}{cccc}
1 & 1 & \ldots & 1 \\
1 & W & \ldots & W^{N-1} \\
1 & \ldots & \ldots & \ldots \\
1 & W^{N-1} & \ldots & W^{N(N-1)}
\end{array}\right]
$$

$\operatorname{dimana} \boldsymbol{W}=e^{\underline{Z \mathrm{Zm} k}}$

\subsection{MODEL KANAL}

Tipe dari derau pada kanal tertentu sangat bervariasi tergantung dari media yang digunakan dan lingkungan yang seperti apa. Makalah ini hanya membahas dua buah tipe kanal yang pertama adalah kanal yang bersifat Gassian yang aditif (AWGN). Dan Kanal Midletone Kelas A yang disederhanakan yang merupakan gabungan antara AWGN sebagai derau latar dan derau impulsive (AWCN). Kemunculan dari derau impulsive ditentukan oleh parameter $m$.

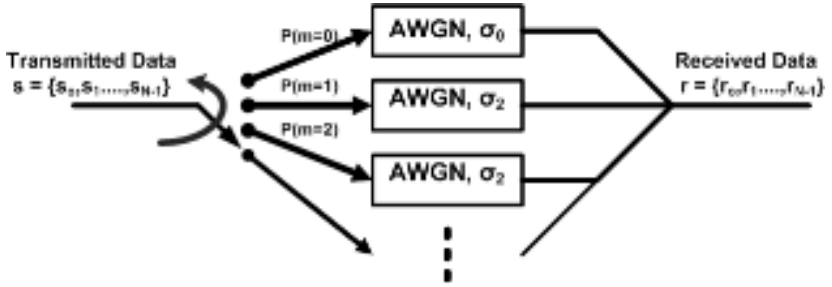

Gambar 3. Model Kanal

Pemilihan antara kanal AWGN dan AWCN ditentukan oleh nilai dari variabel $P(m)$, artinya $P(m)$ adalah variabel yang menentukan apakah data yang ditransmisikan akan dikirim melalui kanal AWGN ataukah kanal AWCN dengan nilai probabilitas tertentu.

\subsubsection{ADDITIVE WHITE GAUSSIAN NOISE $(A W G N)$}

Additive White Gaussian Noise (AWGN) adalah sebuah kanal yang memiliki derau putih (White Noise) dengan distribusi yang bersifat 
Gaussian. Derau putih memiliki energy atau daya yang sama dalam kerapatan spektral dayanya (spectral power density) di rentang frekuensi manapun. Dengan fungsi kemungkinan kerapatannya (probability density function) atau disingkat PDF adalah sebagi berikut

$P(x)=\frac{1}{\sqrt{2 \pi} \sigma} e^{\frac{-\left(x-m_{x}\right)^{2}}{\sigma^{2}}}$

dimana $\boldsymbol{m}_{\boldsymbol{x}}$ adalah rata-rata and $\boldsymbol{\sigma}^{2}$ is the simpangan dari random variabel $\mathrm{x}$. Oleh karena itu,

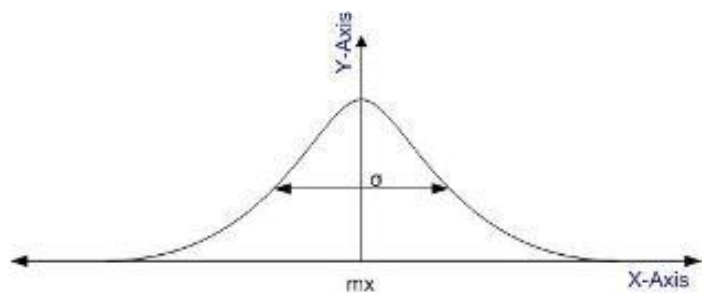

Gambar 4. Fungsi Kerapatan ProbalitasAWGN

PDF dari fungsi tersebut akan bersifat simetris dengan nilai rata-rata adalah $\boldsymbol{m}_{\boldsymbol{x}}$. Kanal AWGN digunakan sebagai model untuk derau latar, interferensi dan banyak model kanal komunikasi lainnya. Gambar 5 memperlihatkan bentuk dari derau putih aditif pada domain waktu.

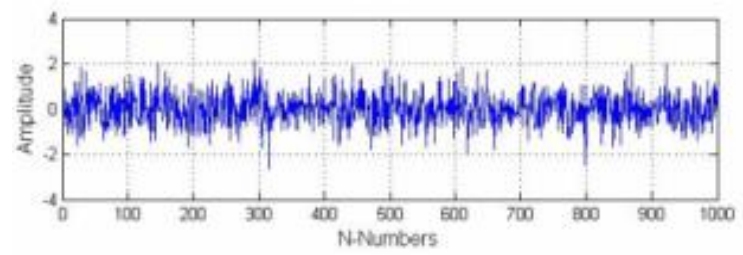

Gambar 5. AWGN dalam kanal

\subsubsection{DERAU IMPULSIF}

Derau impulsif adalah tipe derau yang kemunculannya dalam perioda waktu yang sangat singkat dalam kanal. Daya atau energi yang dihasilkan oleh derau impulsif lebih besar ketimbang daya dari sinyal symbol dan derau latar. Biasanya kita bisa mendeteksi posisi dimana derau impuls terjadi pada rentetan penerimaan simbol data dalam suatu kerangka data (data frame).

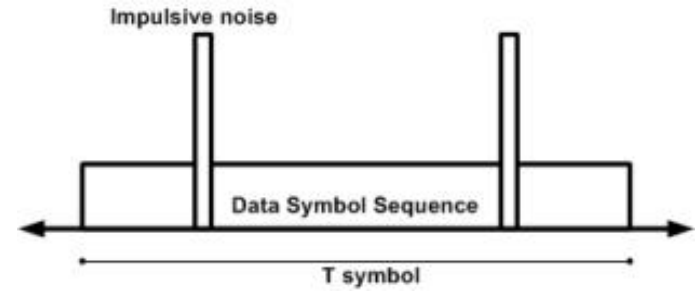

\section{Gambar 6. Derau Impulsif Dalam Kanal}

\subsubsection{MIDLETONE CLASS A CHANNEL $(\mathrm{AWCN})$}

Middle tone class A ( $A W C N)$ adalah model dari kanal dimana memiliki kombinasi antara derau latar dan derau impulsive. Dalam AWCN derau impulsif akan muncul secara acak, artinya tidak setiap saat derau tipe ini muncul dalam kanal. Pada saat mengirimkan data, kemunculan derau impulsif ini ditentukan oleh PDF yang berbentuk distribusi Poisson. Makalah ini hanya membahas kemunculan derau impulsif yang tetap dalam kanal oleh karena itu kanal yang akan kita gunakan dalam penelitian ini kita sebut dengan AWCN yang disederhanakan. Waktu kemunculan derau impulsive dalam kanal sangat sebentar sekali dibandingkan dengan kemunculan derau latar atau AWGN. Secara amplitude derau impulsif memiliki amplitude yang sangat besar. Perbandingan durasi antara derau latar dan derau impulsive dapat dilihat di Gambar 7.

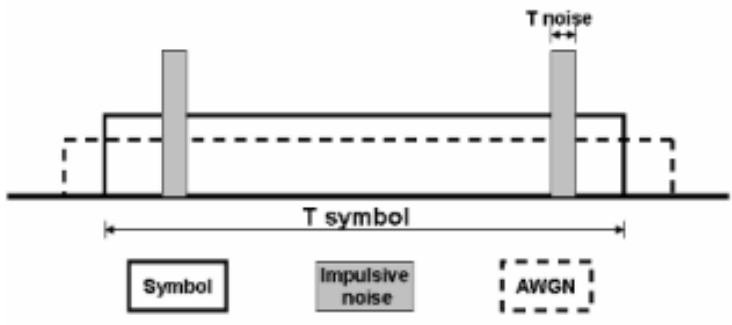

Gambar 7. Kanal Midletone Kelas A (AWCN) Untuk menggambarkan fungsi kerapatan probabilitas digunakan sebuah formula sebagai berikut.

$P(x)=\frac{1}{2 \pi} \sum_{m=0}^{\infty} \frac{1}{\sigma_{m}^{2}} \alpha_{m} e^{-\frac{\|\left. x\right|^{2}}{2 \sigma^{2}}}$

dimana $\alpha_{m}=e^{-A \frac{A^{m}}{m !}}, \sigma_{m}^{2}=\sigma^{2} \frac{\left[m_{A}\right]+T}{1+T}$, dan $\sigma^{2}$ total varians dari derau AWCN, sebagai contoh, $\sigma_{g}^{2}+\sigma_{i}^{2} \cdot T=\frac{\sigma_{g}^{2}}{\sigma_{i}^{2}}$ koefisien perbandingan dari komponen varians yang dimiliki derau latar (AWGN) dengan komponen varians derau impulsif. Sedangkan $A$ adalah impulsif indeks, Apabila $A$ is kecil ( misal $A=0.1$ ), maka derau sangat bersifat impulsif, dan Apabila $(A \rightarrow \infty)$ maka PDF dari AWCN akan menjadi Gaussian atau AWGN. Didalam representasi suatu sampel derau $n$ dapat diformulakan sebagai berikut,

$$
n=X_{G}+\sqrt{K} y
$$


dimana $X_{G}$ adalah derau latar yang bersifat Gaussian dengan rata-rata bernilai 0 dan nilai varians sebesar $\sigma_{G}^{2}, K$ distribusi acaknya terpisah secara statistik ( independent ) yang PDFnya ditentukan oleh parameter $P_{(m)}$ (kemungkinan kemunculan derau impulsif), dan $y$ adalah AWGN dengan nilai ratarata 0 dan varians $\sigma_{G}^{2}$, seperti yang di ilustrasikan pada Gambar 8.

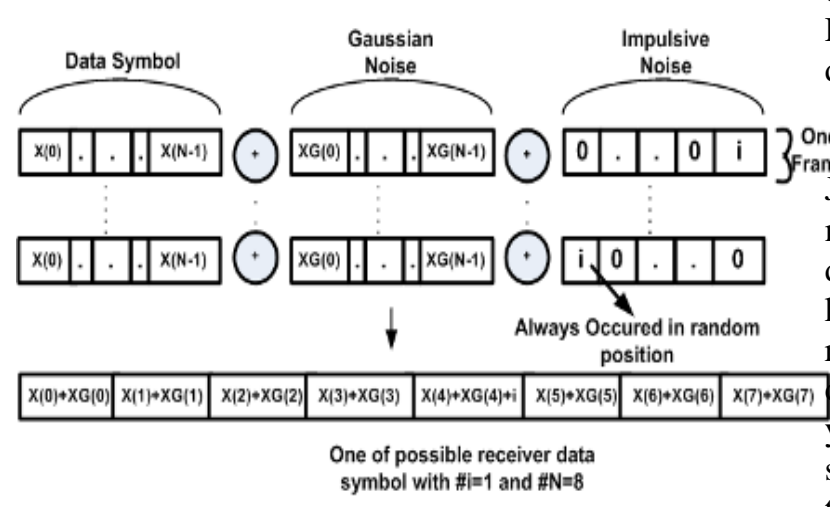

\section{Gambar 8. Kanal AWCN Yang Disederhanakan}

\section{ALGORITMA JACK K. WOLF}

Algoritma koreksi derau impulsif diperkenalkan diperkenalkan pertama kali oleh Jack K. Wolf, yang menjelaskan bahwa terdapat paralelisme antara transmisi OFDM dengan Kode Reed-Solomon.

Dengan menggunakan rudundansi nol yang berurutan dalam symbol Jack K. Wolf berhasil untuk mendeteksi lokasi terjadinya derau impuls dan berapa besar amplitudanya dalam urutan simbol data. Pada akhirnya algoritma ini dapat mengkoreksi kesalahan yang disebabkan oleh derau impuls.
Diagram blok sistem di ilustrasikan pada Gambar 9. Seperti ditunjukkan dalam blok diagram, algoritma Jack K. Wolf memiliki deteksi kesalahan derau impulsif dan estimasi nilai amplitudanya. Tujuan dari deteksi deteksi kesalahan derau impulsif adalah untuk menginformasikan pengamat di mana posisi derau impulsif berada, sedangkan tujuan estimasi amplituda derau impulsif adalah untuk memperkirakan amplituda derau impulsif. Dengan menggunakan informasi ini, sistem akan dapat menghilangkan derau impulsif dari sistem.

Teknik dasar yang digunakan dalam sistem Jack K Wolf adalah sebagai berikut. Sistem akan mengirimkan urutan data simbol diskrit dalam domain waktu yang terdiri dari bilangan real atau kompleks yang DFTnya memiliki nol sebagai redundansi dalam posisi tertentu. Setelah dikirimkan melalui kanal dengan derau impulsif yang bersifat aditif, maka DFT dari urutan data simbol diskrit dalam domain waktu yang diterima tidak akan lagi memiliki angka nol di posisi tersebut. Dikarenakan, nilai-nilai komponen dari urutan yang diterima DFT di posisi ini sudah di pengaruhi oleh derau pada kanal. Dengan asumsi bahwa derau pada kanal hanya derau impulsif, maka strategi untuk mengestimasi lokasi dimana derau impuls itu berada dan berapa besar amplitudanya digunakan. Derau Impuls ini kemudian dihapus/dihilangkan untuk menghasilkan urutan data yang lebih baik di sisi penerima [9]. Jadi rumus dasar dari penjelasan di atas untuk kanal derau impulsif adalah sebagai berikut.

Vektor Data yang ditransmisikan
$\vec{X}=\left\{X_{(0),} X_{(1),} X_{(2),} X_{(a),} X_{(4)} X_{(5), 0,0}\right\}$

dan data vector yang diterima di sisi penerima

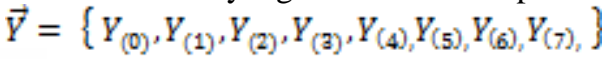

Apabila vektor $\vec{Y}=\left\{Y_{(6)} Y_{(7)}\right\} \neq\{0,0\}$ maka derau impulsive terjadi. Untuk menentukan posisi dimana derau impuls terjadi ditentukan dengan rumus matematika sebagai berikut,

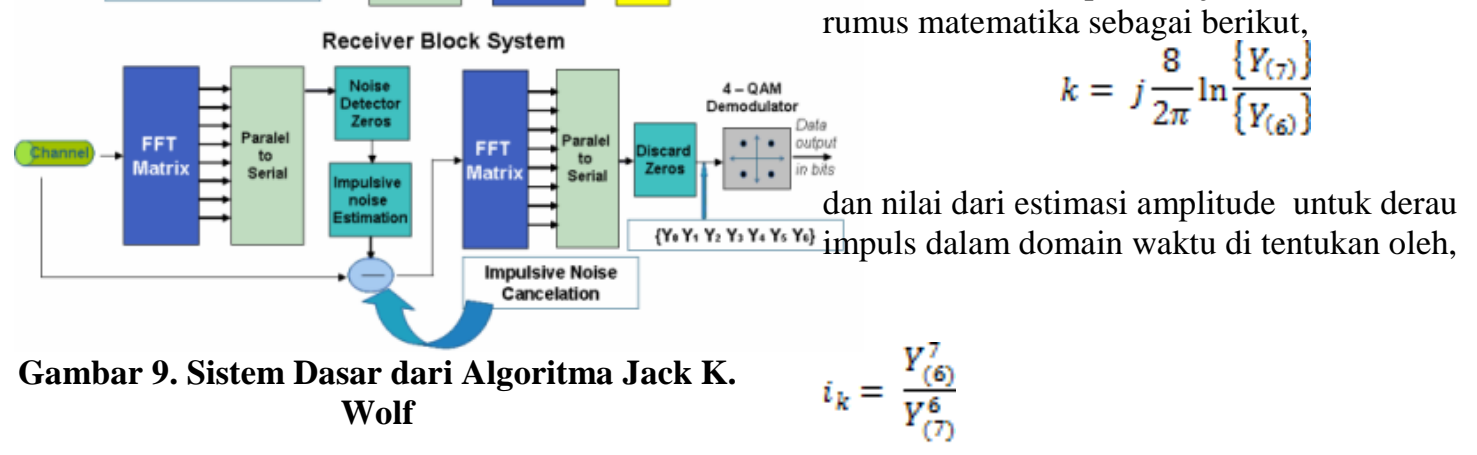


Menggunakan formula 3 dan 3 maka amplitude dan posisi dari derau impulsive dapat di estimasi bahkan di hilangkan dari transmisi data. Sehingga data yang diterima dari transmisi data adalah sebagai berikut

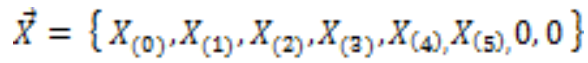

yang harus memiliki nilai yang sama dengan

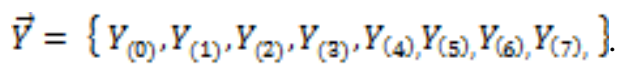

Apabila sama artinya kita telah menghilangkan derau impulsif dari sistem. Untuk penjelasan lebih lanjut akan diberikan contohh sebagai berikut. Di asumsikan bahwa 6 simbol data dari 4-QAM ditambahkan oleh 2 buah nilai nol sebagi data redundan untuk setiap satu blok data. Sistem akan diberikan derau impulsif dan kemudian sistem akan berusaha untuk mengestimasi amplituda derau dan di posisi mana yang estimasi amplitude tersebut di negasikan dari data vector yang diterima.

Contoh: $\overrightarrow{\mathbb{X}}$ merupakan bentuk kompleks data transmisi untuk 4 - QAM.

$\vec{X}=\left\{1+i_{x} 1-i_{s}-1-i_{x} 1+i_{x} 1+i_{x}-1+i\right\}$

kemudian tambahkan redundansi nol ,

$\vec{X}=\left\{1+i_{x} 1-i_{x}-1-i_{x} 1+i_{x} 1+i_{x}-1+i_{x}, 0,0\right\}$

setelah dikalikan dengan 8-IFFT matriks,

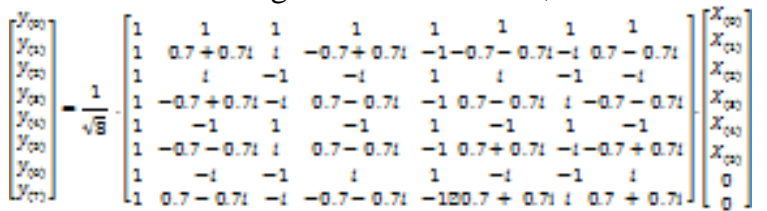

maka 1 bisa dikalkulasikan sebagai berikut,

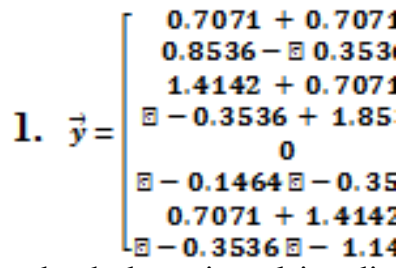

sebuah derau impulsive di tambahkan di posisi ke 4 di sisi vektor penerima $\vec{y}$, contoh.

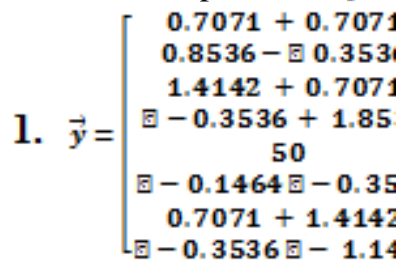

dimana ditranformasikan vektor data di sisi penerima ke dalam frekuensi domain dengan FFT matriks, yang dapat digambarkan sebagai berikut

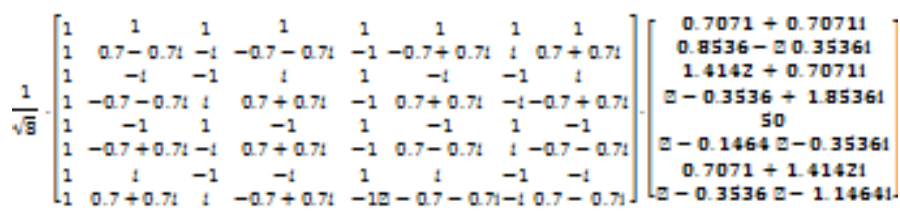

dan vektor 1 menjadi,

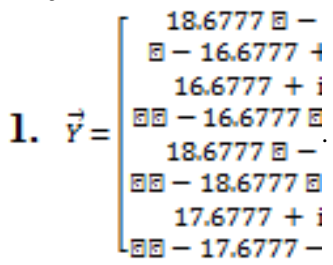

Nilai amplitude dari derau impulsive $i_{k}$ didalam domain waktu di hitung dengan persamaan (3) dan dikalikan dengan faktor normalisasi.

$i_{k}=50$

$$
i_{k}=\frac{(17.6777+1)^{7}}{\left(-17.6777-[1)^{6}\right.} \cdot(\sqrt{8})
$$

dan posisi dari derau impuls berada pada urutan data ke,

$$
k=j \frac{8}{2 \pi} \ln \left(\frac{-17 \cdot 6777-i}{17 \cdot 6777+i}\right)
$$

$k=4$

Setelah prosedur diatas, kemudian kita harus mengurangi vektor $\vec{y}$ dengan amplitude derau impuls di posisi keempat dengan urutan dimulai dengan 0 .

$$
\text { 1. } \vec{y}=\left[\begin{array}{c}
0.7071+0.7071 \mathrm{i} \\
0.8536-0.3536 \mathrm{i} \\
1.4142+0.7071 \mathrm{i} \\
\square-0.3536+1.8536 \\
50 \\
\square-0.1464[-0.353 i \\
0.7071+1.4142 \mathrm{i} \\
\square-0.3536[-1.146
\end{array}\right.
$$

yang akan dikalikan lagi dengan FFT matriks maka simbol data yang sudah di koreksi akan sama dengan data simbol yang ditransmisikan.

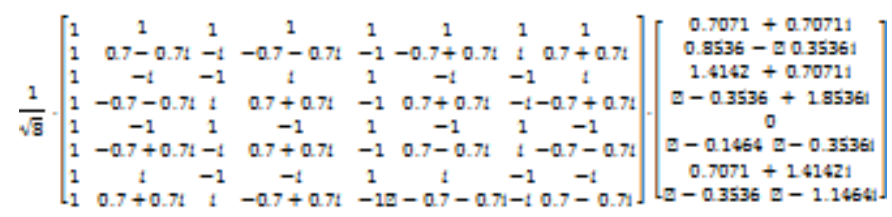

Dan hasilnya adalah, 


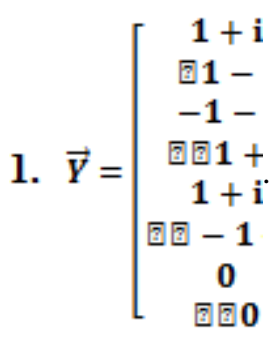

Terakhir, simbol data yang bernilai nol yang digunakan sebagai redudansi akan dihapus di sisi penerima. Kemudian kita mendapatkan vektor disisi penerima akan sama dengan vektor data yang ditransmisikan. Contoh ini menunjukan bahwa Algoritma Jack K. Wolf dapat mengkoreksi derau impulsive additive yang terjadi di dalam kanal. Simulasi di lakukan untuk merepresentasikan karakteristik dari Algoritma koreksi derau impulsive Jack $\mathrm{K}$. Wolf dengan menggunakan kanal AWCN yang disederhanakan. Sistem simulasi yang dilakukan digunakan satu derau impulsive yang akan muncul didalam kanal di setiap blok data yang diterima. Hasil berbentuk berupa gambar kurva antara performa Bit Error Rate (BER) terhadap jarak yang bermacam macam dari Signal to Noise Ratio(SNR).

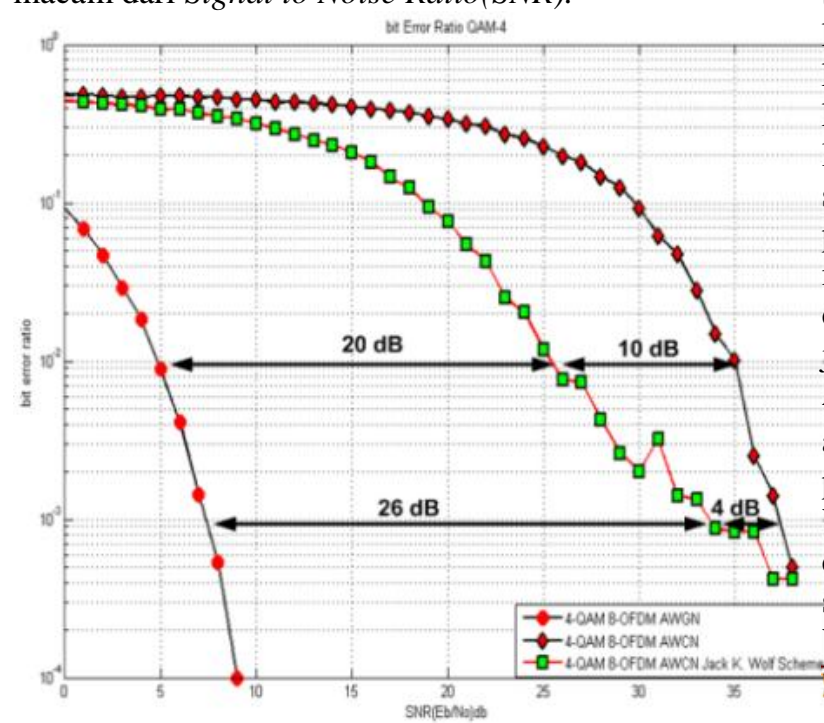

Gambar 9. Simulasi Algoritma Jack K. Wolf

Sebagaimana di sebutkan sebelumnya algoritma Jack K. Wolf mampu mendeteksi satu derau impulsive yang muncul di dalam kanal dan kemudian mengoreksinya di sisi penerima. Kasus lain di simulasikan dengan sistem kanal yang ditambahkan dengan derau latar selain derau impulsive pada akhirnya sistem memiliki kanal AWCN dengan parameter $\mathrm{T}=10^{-3}$, sebagai komparator energy anatar derau impulsive dan derau latar.

Dari gambar 9 dapat dilihat bahwa performansi BER yang nilainya $10^{-2}$ dapat dicapai dari yang sebelumnya di SNR $35 \mathrm{~dB}$ menjadi 25 $\mathrm{dB}$, sistem ini memiliki performa lebih baik sebesar $10 \mathrm{~dB}$ dalam SNR.

\section{MODIFIKASI ALGORITMA JACK K. WOLF UNTUK MENGELEMINASI DERAU IMPULSIF}

Algoritma Jack K. Wolf digunakan untuk mendeteksi posisi dan melakukan estimasi energi dari derau impulsif yang akhirnya dapat mengkoreksi data simbol yang ada pada sisi penerima. Sistem ini membedakan teknik yang ada yaitu teknik yang pertama adalah mendeteksi posisi dan teknik yang kedua adalah melakukan estimasi nilai amplituda derau impulsive. Sehingga hasilnya sangat bergantung kepada teknik pendeteksian posisi dimana derau impulsif berada akan sangat mempengaruhi hasil keselurah sistem. Ketidak tergantungan teknik pendeteksian posisi dengan teknik estimasi amplitude dapat menyebabkan dua kesalahan pada sistem. Kesalahan yang pertama kesalahan pada saat pendeteksian dan yang kedua kesalahan pada saat estimasi. Semakin besar derau latar yang terjadi pada suatu sistem menyebabkan semakin besar pula kesalahan yang terjadi pada pendeteksian posisi derau impulsif yang menyebabkan kesalahan pada saat subtraksi derau di sistem bukannya menghilangkan derau tetapi justru menambah derau yang bersifat impulsive. Analisa di lakukan dan dilakukan modifikasi pada algoritma ini, contohnya $\overrightarrow{\boldsymbol{Y}}$ adalah vektor FFT disisi penerima. Redudansi yang bernilai nol di posisi Y[6] dan Y[7] di observasi. Jika sistem memiliki derau impulsive yang aditif dan derau AWGN sebagai derau latar, maka vektor di sisi penerima Y[6] dan Y[7] adalah $\overrightarrow{[6]}=\left\{\overrightarrow{X_{[\boxminus]}}+N_{g}+I_{[6]}\right\}$

$$
\begin{aligned}
& \overrightarrow{Y_{[6]}}=\left\{\overrightarrow{X_{[6]}}+N_{g}+\alpha^{6 . k} \cdot i_{k}\right\} \\
& \underset{Y_{[\eta]}}{\overrightarrow{\text { dan }}}=\left\{\overrightarrow{X_{[\eta]}}+N_{g}+I_{[\eta]}\right\} \\
& \overrightarrow{Y_{[j]}}=\left\{\overrightarrow{X_{[j]}}+N_{g}+\alpha^{7 \cdot k} i_{k}\right\} \\
& \text { dimana }
\end{aligned}
$$$$
\overrightarrow{X_{[\sqrt{6]}]}}=0 \text { dan } \overrightarrow{X_{[7]}}=0, N_{g}=0, I=, i=, k=, \alpha=
$$ 
Untuk mendeteksi posisi derau impulsif digunakan formula 2 yaitu,

$k=j \frac{8}{2 \pi} \ln \frac{\left\{N_{g}+\alpha^{7 . k} \cdot i_{k}\right\}}{\left\{N_{g}+\alpha^{6 . k} \cdot i_{k}\right\}}$

Hasilnya menunjukan derau latar yang bersifat Gauss mempengaruhi estimasi posisi derau impulsive berada. Dan formula (3) digunakan untuk melakukan estimasi amplituda derau impulsif.

$i_{k}=\frac{\left(N_{g}+I_{6}\right)^{7}}{\left(N_{g}+I_{7}\right)^{6}}$

$i_{k}=\frac{\left(N_{g}+\alpha^{6 . k} \cdot i_{k}\right)^{7}}{\left(N_{g}+\alpha^{7 \cdot k} \cdot i_{k}\right)^{6}}$

Formula (3) akan menguatkan derau latar Gauss yang berada di vektor penerima. Sehingga mengakibatkan estimasi amplituda dari derau impulsif tidak akan mendekatkan dengan nilai yang sebenarnya ( akan ada gap antara hasil estimasi dengan nilai yang sebenarnya) Tabel 1 menunjukan gap yang terjadi antara nilai estimasi dan nilai yang sebenarnya

\section{Tabel 1. Estimasi Nilai Amplituda Derau Impulsif di Algoritma Jack K. Wolf}

\begin{tabular}{|c|c|c|c|c|}
\hline SNR & estimation of amplitude & impulsive noise & gap $(\Delta)$ & $\mathrm{E}(\mathrm{n}) / \mathrm{bit}$ \\
\hline 0 & $-40.00+56.45 \mathrm{i}$ & $-16.70+26.21 \mathrm{i}$ & $-23.30+30.24 \mathrm{i}$ & 114.95 \\
\hline 1 & $31.13-11.90 \mathrm{i}$ & $30.54-13.29 \mathrm{i}$ & $0.59+1.40 \mathrm{i}$ & 0.29 \\
\hline 2 & $-41.34+11.80 \mathrm{i}$ & $-17.98+20.09 \mathrm{i}$ & $-23.36-8.29 \mathrm{i}$ & 76.78 \\
\hline 3 & $-15.70+8.66 \mathrm{i}$ & $-30.02+10.96 \mathrm{i}$ & $14.32-2.30 \mathrm{i}$ & 26.28 \\
\hline 4 & $75.82-5.30 \mathrm{i}$ & $58.36+4.70 \mathrm{i}$ & $17.46-10.00 \mathrm{i}$ & 50.59 \\
\hline 5 & $20.66-0.73 \mathrm{i}$ & $27.87-15.35 \mathrm{i}$ & $-7.21+14.62 \mathrm{i}$ & 33.21 \\
\hline 6 & $-5.57-22.00 \mathrm{i}$ & $-3.55-24.43 \mathrm{i}$ & $-2.03+2.43 \mathrm{i}$ & 1.25 \\
\hline 7 & $14.60+24.32 \mathrm{i}$ & $10.12+15.15 \mathrm{i}$ & $4.48+9.16 \mathrm{i}$ & 13.01 \\
\hline 8 & $-17.60+9.66 \mathrm{i}$ & $-21.06+14.07 \mathrm{i}$ & $3.46-4.41 \mathrm{i}$ & 3.92 \\
\hline 9 & $-24.28-0.68 \mathrm{i}$ & $-23.21-3.81 \mathrm{i}$ & $-1.06+3.13 \mathrm{i}$ & 1.37 \\
\hline 10 & $2.77-14.51 \mathrm{i}$ & $2.18-18.87 \mathrm{i}$ & $0.59+4.36 \mathrm{i}$ & 2.42 \\
\hline 11 & $3.76+3.89 \mathrm{i}$ & $1.56+5.12 \mathrm{i}$ & $2.20-1.24 \mathrm{i}$ & 0.80 \\
\hline 12 & $0.99-8.88 \mathrm{i}$ & $-5.25-5.68 \mathrm{i}$ & $6.25-3.20 \mathrm{i}$ & 6.16 \\
\hline 13 & $23.84+3.35 \mathrm{i}$ & $24.11-0.87 \mathrm{i}$ & $-0.27+4.23 \mathrm{i}$ & 2.24 \\
\hline 14 & $5.39+5.24 \mathrm{i}$ & $3.41+6.89 \mathrm{i}$ & $1.99-1.66 \mathrm{i}$ & 0.84 \\
\hline 15 & $-9.89-1.51 \mathrm{i}$ & $-5.08+5.20 \mathrm{i}$ & $-4.81-6.71 \mathrm{i}$ & 8.52 \\
\hline 16 & $-12.86+1.05 \mathrm{i}$ & $-12.20+3.91 \mathrm{i}$ & $-0.66-2.86 \mathrm{i}$ & 1.08 \\
\hline 17 & $6.13-4.23 \mathrm{i}$ & $6.67-5.68 \mathrm{i}$ & $-0.54+1.46 \mathrm{i}$ & 0.30 \\
\hline 18 & $8.97-10.25 \mathrm{i}$ & $5.74-6.97 \mathrm{i}$ & $3.23-3.28 \mathrm{i}$ & 2.65 \\
\hline 19 & $-3.27+5.11 \mathrm{i}$ & $-3.80+5.78 \mathrm{i}$ & $0.54-0.67 \mathrm{i}$ & 0.09 \\
\hline 20 & $14.02-4.66 \mathrm{i}$ & $13.50-3.61 \mathrm{i}$ & $0.52-1.05 \mathrm{i}$ & 0.17 \\
\hline 21 & $-1.91-8.85 \mathrm{i}$ & $-1.06-1.22 \mathrm{i}$ & $-0.85-7.63 \mathrm{i}$ & 7.36 \\
\hline 22 & $0.47-5.61 \mathrm{i}$ & $0.29-5.95 \mathrm{i}$ & $0.18+0.34 \mathrm{i}$ & 0.02 \\
\hline 23 & $0.66+0.97 \mathrm{i}$ & $0.75+1.10 \mathrm{i}$ & $-0.09-0.13 \mathrm{i}$ & 0.00 \\
\hline 24 & $-3.54+4.84 \mathrm{i}$ & $-1.97+5.52 \mathrm{i}$ & $-1.56-0.68 \mathrm{i}$ & 0.36 \\
\hline 25 & $5.99-1.80 \mathrm{i}$ & $3.95-1.41 \mathrm{i}$ & $2.04-0.39 \mathrm{i}$ & 0.54 \\
\hline 26 & $0.26+0.95 \mathrm{i}$ & $0.16+1.93 \mathrm{i}$ & $0.10-0.98 \mathrm{i}$ & 0.12 \\
\hline 27 & $1.07-3.83 \mathrm{i}$ & $1.48-4.26 \mathrm{i}$ & $-0.41+0.43 \mathrm{i}$ & 0.04 \\
\hline 28 & $-1.31-0.35 \mathrm{i}$ & $-1.34+0.59 \mathrm{i}$ & $0.03-0.94 \mathrm{i}$ & 0.11 \\
\hline 29 & $3.89-2.52 \mathrm{i}$ & $3.82-3.01 \mathrm{i}$ & $0.08+0.49 \mathrm{i}$ & 0.03 \\
\hline 30 & $-0.51+0.91 \mathrm{i}$ & $-0.68+1.01 \mathrm{i}$ & $0.17-0.09 \mathrm{i}$ & 0.00 \\
\hline & & & & \\
\hline
\end{tabular}

Modifikasi dilakukan untuk mengurai permasalahan ini guna meningkatkan performa algoritma Jack K. Wolf. Algoritma ini menunjukan independensi antara teknik estimasi posisi dan amplituda derau dapat meningkatkan kemungkinan terjadinya kesalahan di bagian sub sistem pengeleminasian derau impulsif. Dengan cara terlebih dahulu mengasumsikan posisi derau telah diketahui sebelumnya, sehingga dependensi antara posisi dan estimasi amplituda dilakukan guna meningkatkan performa estimasi amplituda.

Dua urutan vektor penerima terkahir kita observasi dengan seksama yaitu $Y_{[6]}$ dan $Y_{[7]}$ adalah. Dua buah sindrom di set dengan nilai nol di sisi pengirim, yang kemudian di sisi penerima nilainya tidak akan menjadi nol akibat derau latar dan impulsif dalam domain waktu yang terjadi dalam kanal. Dari penurunan DFT kita dapatkan,

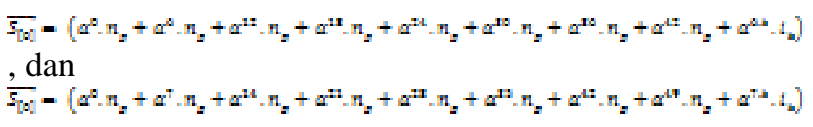
, dan

Nilai sindrom yang didapat merupakan hasil superposisi dari derau aditif baik yang bersifat impulsif dan latar. Dikarenakan derau latar (AWGN) sangat kecil nilainya bila dibandingkan dengan derau impulsif maka derau latar yang berdistribusi Gauss dapat di abaikan dalam sistem. Dengan begitu kita dapatkan persamaan dari kedua sindrom yang lebih sederhana untuk menentukan nilai amplitude derau impulsif yaitu,

$i_{k}=\left(\alpha^{-6 k k} \cdot \overrightarrow{S_{[0]}}\right)$

dan 
$i_{k}=\left(\alpha^{-7 \cdot k} \cdot \overrightarrow{S_{[1]}}\right)$

Karena $n_{s} \times i_{k}$, maka,

$i_{k}=\left(\alpha^{-6 k^{*}} \cdot \alpha^{6 \cdot k}, i_{k}\right)$

dan

$i_{k}=\left(\alpha^{-7 . k} \cdot \alpha^{7 . k} \cdot i_{k}\right)$

Dengan asumsi nilai rata-rata dari $i_{k}$ digunakan untuk mengurangi efek dari derau latar Gauss yang ada, maka hasilnya adalah,

$i_{k}=\frac{\left(\alpha^{-6 \cdot k} \cdot \overrightarrow{S_{[0]}}\right)+\left(\alpha^{-7 \cdot k} \cdot \overrightarrow{S_{[1]}}\right)}{2}$

Formula digunakan untuk estimasi nilai amplitude derau impulsive tanpa factor penguatan Gauss. Sebagian kecil dari derau Gauss masih tetap ditemukan namun estimasi amplitude derau impulsive yang dihasilkan lebih mendekati nilai sebenarnya.

Tabel 4 menunjukan hasil modifikasi algoritma Jack K. Wolf, akurasi estimasi amplitude derau impulsive meningkat secara signifikan apabila dibandingkan dengan tabel 3.

Tabel 1. Estimasi Nilai Amplituda Derau Impulsif di Modifikasi Algoritma Jack K. Wolf

\begin{tabular}{|c|c|c|c|c|}
\hline SNR & estimation of amplitude & impulsive noise & $\operatorname{delta}(\Delta)$ & $\mathrm{E}[\mathrm{n}]$ \\
\hline 0 & $18.7064-9.7883 i$ & $18.2335-8.6236 \mathrm{i}$ & $0.4729-1.1647 \mathrm{i}$ & \\
\hline 1 & $-7.5948-63.7886 \mathrm{i}$ & $-7.0981-63.1962 \mathrm{i}$ & $-0.4968-0.5924 \mathrm{i}$ & \\
\hline 2 & $-36.6425-33.8468 \mathrm{i}$ & $-36.4328-33.5834 \mathrm{i}$ & $-0.2097-0.2634 \mathrm{i}$ & \\
\hline 3 & $-35.6507+36.1111 \mathrm{i}$ & $-35.6216+35.2507 i$ & $-0.0291+0.8604 \mathrm{i}$ & \\
\hline 4 & $19.6228-14.3607 \mathrm{i}$ & $20.0787-13.3360 \mathrm{i}$ & $-0.4559-1.0247 \mathrm{i}$ & \\
\hline 5 & $-10.8515+15.1812 \mathrm{i}$ & $-11.1103+15.4826 \mathrm{i}$ & $0.2588-0.3014 \mathrm{i}$ & \\
\hline 6 & $7.1397-49.3950 \mathrm{i}$ & $8.0592-49.0371 \mathrm{i}$ & $-0.9195-0.3579 \mathrm{i}$ & \\
\hline 7 & $17.4667-22.6385 \mathrm{i}$ & $17.8605-24.1051 \mathrm{i}$ & $-0.3938+1.4666 \mathrm{i}$ & \\
\hline 8 & $1.9650-2.4741 \mathrm{i}$ & $2.8794-2.3497 i$ & $-0.9144-0.1245 \mathrm{i}$ & \\
\hline 9 & $-5.4614-3.3150 \mathrm{i}$ & $-5.5706-3.5701 \mathrm{i}$ & $0.1092+0.2551 \mathrm{i}$ & \\
\hline 10 & $15.2771-13.8918 \mathrm{i}$ & $15.4141-14.1585 i$ & $-0.1370+0.2667 \mathrm{i}$ & \\
\hline 11 & $2966-6.7367 \mathrm{i}$ & $28.2054-6.8672 \mathrm{i}$ & $0.0912+0.1306 \mathrm{i}$ & \\
\hline 12 & $-11.7227+8.2317 \mathrm{i}$ & $-11.2512+8.4589 \mathrm{i}$ & $-0.4715-0.2273 \mathrm{i}$ & \\
\hline 13 & $-19.6265-11.0061 \mathrm{i}$ & $-19.7192-11.2043 \mathrm{i}$ & $0.0927+0.1983 \mathrm{i}$ & \\
\hline 14 & $-6.9702+0.1812 \mathrm{i}$ & $-7.0444+0.3618 \mathrm{i}$ & $0.0742-0.1807 \mathrm{i}$ & \\
\hline 15 & $-4.2998-3.7772 \mathrm{i}$ & $-4.0681-3.6116 \mathrm{i}$ & $-0.2317-0.1657 \mathrm{i}$ & \\
\hline 16 & $-3.5657-8.5031 i$ & $-3.6607-8.4582 \mathrm{i}$ & $0.0950-0.0449 \mathrm{i}$ & \\
\hline 17 & $-5.5956+8.5250 \mathrm{i}$ & $-5.8683+8.7532 \mathrm{i}$ & $0.2727-0.2282 \mathrm{i}$ & \\
\hline 18 & $-8.4504-9.7963 i$ & $-8.7413-9.6691 \mathrm{i}$ & $0.2909-0.1272 \mathrm{i}$ & \\
\hline 19 & $2.4779-5.5775 i$ & $2.5799-5.5635 \mathrm{i}$ & $-0.1020-0.0139 \mathrm{i}$ & \\
\hline 20 & $-3.7420-0.5437 \mathrm{i}$ & $-3.7357-0.5777 \mathrm{i}$ & $-0.0063+0.0340 \mathrm{i}$ & \\
\hline 21 & $0.0002+0.5239 \mathrm{i}$ & $-0.0911+0.6349 \mathrm{i}$ & $0.0913-0.1110 \mathrm{i}$ & \\
\hline 22 & $3.9447-5.5329 \mathrm{i}$ & $3.8234-5.4523 \mathrm{i}$ & $0.1213-0.0806 \mathrm{i}$ & \\
\hline 23 & $4.2425+1.0371 \mathrm{i}$ & $4.2879+1.0349 \mathrm{i}$ & $-0.0454+0.0022 \mathrm{i}$ & \\
\hline 24 & $-2.8481+2.1160 \mathrm{i}$ & $-2.8168+2.1525 \mathrm{i}$ & $-0.0313-0.0364 \mathrm{i}$ & \\
\hline 25 & $-5.5461+3.6333 \mathrm{i}$ & $-5.5389+3.5910 \mathrm{i}$ & $-0.0071+0.0423 \mathrm{i}$ & \\
\hline 26 & $0.7715-2.6433 i$ & $0.8291-2.6866 \mathrm{i}$ & $-0.0577+0.0433 \mathrm{i}$ & \\
\hline 27 & $-2.7622-1.0414 i$ & $-2.7233-1.0228 \mathrm{i}$ & $-0.0389-0.0186 \mathrm{i}$ & \\
\hline 28 & $-2.2681-0.0252 \mathrm{i}$ & $-2.2943+0.0131 i$ & $0.0262-0.0383 \mathrm{i}$ & \\
\hline 29 & $1.1972+0.0084 \mathrm{i}$ & $1.0959+0.0186 \mathrm{i}$ & $0.1013-0.0102 \mathrm{i}$ & \\
\hline 30 & $-0.8689+0.3665 \mathrm{i}$ & $-0.8570+0.4142 i$ & $-0.0119-0.0477 \mathrm{i}$ & \\
\hline
\end{tabular}

Simulasi dilakukan untuk memberikan bukti peningkatan modifikasi algoritma yang dilakukan dan membandingkannya dengan algoritma aslinya. Formula 4 diimplementasikan kedalam sistem dengan kanal yang mengandund derau latar AWGN dan impulsive yang muncul pada setiap blok simbol data disisi penerima. Dengan nilai variabel $\mathrm{T}=10^{-3}$ sebagai nilai perbandingan energy atau daya derau impulsive dengan derau latar, dan asumsi bahwa posisi derau impulsive telah diketahui sebelumnya.

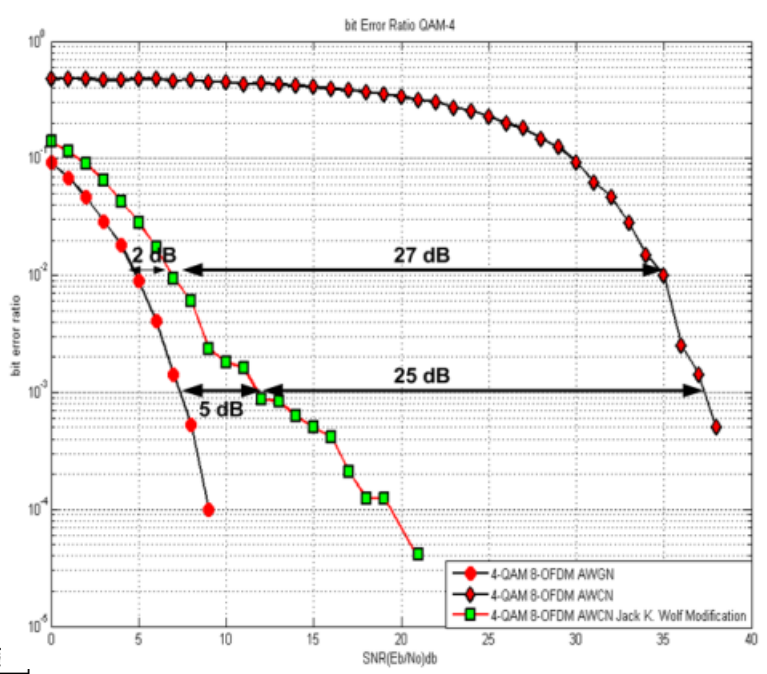

Gambar 10. Modifikasi Algoritma Jack K. Wolf (1) 整的BER sebesar $27 \mathrm{~dB}$ dari kurva AWCN dengan nilai 10066BER di $10^{-3}$ artinya setiap 1000 bit yang dikirim 1112hanya ada satu bit yang error. 0342 14 KESIMPULAN 158 126 improve the BER performance, the Moore${ }_{00026}^{000} \mathrm{P}$ enrose pseudo inverse matrix algorithm is .0027proposed and simulate in this paper. This algorithm . 002allgorithm for correcting the impulsive noise error 0.006 000 here the number of zero is equal to the number of 0.0033

Dosnoise). The BER of this algorithm using simplified AWCN channel model has $29 \mathrm{~dB}$ gain in BER value of $10^{-3}$ from the simplified AWCN BER curve for an additive impulsive noise error in the channel.

\section{REFERENCES}

[1] Thomas Britz. The moore-penrose inverse of a free matrix. Electronic Journal of Linear Algebra, 16:208-215, 2007. 
[2] Cudenver. The vandermonde matrix. http://www-

math.cudenver.edu/ rrosterm/crypt_proj/n ode6.html, March 2002.

[3] J. Cioffi L. Hoo S. K. Wilson C. Tellambura M. Friese A. Mody Gordon Stuber, Ye Geoffrey Li. Orhotgonal Frequency Division Multiplexing For Wireless Communications. Springer, 2006.

[4] J. Haering and A. J. H. Vinck. Coding for impulsive noise channels,. Proceeding of International Symposium on Power Line Communications and Its Applications, pages 103-108, 2001.

[5] S. Haykin. Communications System. John Wiley Son, 2001.

[6] D. Middleton. canonical and quasicanonical probability models of class a interference. IEEE

[7] Transactions on Electromagnetic Compatibility, 45(5):1456-1457, 1999.

[8] John G. Proakis. Digital Communications. McGraw-Hill, 2001.

[9] Jack K. Wolf. Redundancy, the discrete fourier transform, and impulse noise cancellation. IEEE Transactions on Communications, 30(3):458-460, 1983. 